\title{
Acetylcholine-Induced Potassium Current of Guinea Pig Outer Hair Cells: Its Dependence on a Calcium Influx through Nicotinic-Like Receptors
}

\author{
Christophe Blanchet, Carlos Eróstegui, Masashi Sugasawa, and Didier Dulon \\ Laboratoire d'Audiologie Expérimentale, Institut National de la Santé et de la Recherche Médicale, and Université de \\ Bordeaux II, Hôpital Pellegrin, 33076 Bordeaux, France
}

\begin{abstract}
The cholinergic efferent inhibition of mammalian outer hair cells $(\mathrm{OHCs})$ is mediated by a hyperpolarizing $\mathrm{K}^{+}$current. We have made whole-cell tight-seal recordings from single OHCs isolated from the guinea pig cochlea to characterize the mechanism by which acetylcholine $(\mathrm{ACh})$ activates $\mathrm{K}^{+}$channels. After ACh application, $\mathrm{OHCs}$ exhibited a biphasic response: an early depolarizing current preceding the predominant hyperpolarizing $\mathrm{K}^{+}$current. The current-voltage $(I-V)$ relationship of the ACh-induced response displayed an $\mathrm{N}$-shape, suggesting the involvement of $\mathrm{Ca}^{2+}$ influx. When whole-cell recording was combined with confocal calcium imaging, we simultaneously observed the ACh-induced $\mathrm{K}^{+}$current $\left(I_{\mathrm{K}(\mathrm{ACh})}\right)$ and a $\mathrm{Ca}^{2+}$ response restricted to the synaptic area of the cell. This $I_{\mathrm{K} \text { (ACh) }}$ could be prevented by loading $\mathrm{OHCs}$ with $10 \mathrm{~mm}$ of the fast $\mathrm{Ca}^{2+}$ buffer bis(2-aminophenoxy)ethane- $N, N, N^{\prime}, N^{\prime}$-tetra-acetic
\end{abstract}

acid (or BAPTA), therefore allowing the observation of the ACh-induced early current in isolation. This early current revealed nicotinic features because it activated with an intrinsic delay in the millisecond range, reversed nearly in between potassium and sodium equilibrium potentials, and was blocked by curare. However, it was strongly reduced in the absence of external $\mathrm{Ca}^{2+}$, and its $I-V$ relationship displayed an unusual outward rectification at positive membrane potentials and an inward rectification below $60 \mathrm{mV}$. The results indicate that the cholinergic response of mammalian $\mathrm{OHCs}$ involves a "nicotiniclike" nonspecific cation channel through which $\mathrm{Ca}^{2+}$ enters and triggers activation of nearby $\mathrm{Ca}^{2+}$-dependent $\mathrm{K}^{+}$channels.

Key words: outer hair cell; $\mathrm{Ca}^{2+}$; acetylcholine; nicotinic receptor; $\mathrm{Ca}^{2+}$-activated $\mathrm{K}^{+}$channel; caged-Ca $\mathrm{Ca}^{2+}$; Fluo-3; patch clamp; confocal microscopy
In the mammalian cochlea, outer hair cells (OHCs) receive an inhibitory efferent innervation (Galambos, 1956) that is essentially cholinergic (Bobbin and Konishi, 1971; Norris and Guth, 1974) (for review, see Eybalin, 1993). Recently, Housley and Ashmore (1991) have shown that acetylcholine (ACh) activates a hyperpolarizing $\mathrm{K}^{+}$current $\left(I_{\mathrm{K}(\mathrm{ACh})}\right)$ in isolated mammalian OHCs. Because $I_{\mathrm{K}(\mathrm{ACh})}$ was prevented in a $\mathrm{Ca}^{2+}$-free extracellular medium and showed short latency, Housley and Ashmore (1991) suggested the involvement of $\mathrm{Ca}^{2+}$ influx, through cholinergic ionotropic receptors, which in turn activates $\mathrm{K}^{+}$channels. More recently, Eróstegui et al. (1994a,b) provided additional data supporting a $\mathrm{Ca}^{2+}$ influx.

To date, however, there is no direct evidence of an AChactivated ionotropic current in mammalian OHCs. Kakehata et al. (1993) have reported results supporting the existence of a metabotropic receptor linked to calcium mobilization via the inositol triphosphate $\left(\mathrm{IP}_{3}\right)$ cascade. An ACh-activated ionotropic current has been demonstrated and characterized in avian hair cells by Fuchs and Murrow (1992a,b). Although pharmacological studies have demonstrated that the ACh responses of both mammalian and avian hair cells display similar mixed nicotinic-muscarinic

\footnotetext{
Received Nov. 13, 1995; revised Jan. 18, 1996; accepted Jan. 25, 1996.

This study was supported by Institut National de la Santé et de la Recherche Médicale (INSERM) and the Conseil Régional d'Aquitaine. C.B. has obtained a fellowship from the Ministère de la Recherche et de l'Espace for his thesis. C.E. is a visiting fellow from Bolivia supported by INSERM and the Fondation Pour la Recherche Médicale (Paris, France). M.S. is a visiting research fellow from the University of Tokyo. We thank Christophe Mulle and Allen Ryan for their helpful discussion concerning this manuscript.

Correspondence should be addressed to Didier Dulon at the above address.

Copyright (C) 1996 Society for Neuroscience $0270-6474 / 96 / 162574-11 \$ 05.00 / 0$
}

features (Housley and Ashmore, 1991; Fuchs and Murrow, 1992b; Eróstegui et al., 1994a), it is worth mentioning that avian hair cells differ greatly from mammalian OHCs. In particular, chick hair cells encode for low acoustic frequencies $(\leq 5 \mathrm{kHz})$ and show electrical tuning (Fuchs et al., 1988). In contrast, mammalian OHCs do not display electrical resonance but have unique fast electromotile properties that are believed to be the basis of the cochlear amplifier (Brownell et al., 1985; Ashmore, 1987).

Interestingly, Elgoyhen et al. (1994) have discovered recently a novel nicotinic $\mathrm{ACh}$ receptor subunit $\alpha 9$ that, when expressed as homomeric complex, displays an unusual pharmacological profile similar to that seen in hair cells. Using in situ hybridization, Elgoyhen et al. (1994) also provided evidence for $\alpha 9$ gene expression in rat OHCs. Although these observations strongly argue in favor of the nicotinic nature of the cholinergic receptor of mammalian $\mathrm{OHCs}$, this remains unproved because a cholinergic ionotropic current has not been observed in these mammalian cells.

The aim of our study, therefore, was to characterize further the cholinergic response of guinea pig OHCs by determining whether an ACh receptor channel is involved. Using the whole-cell patchclamp technique, we show that, in mammalian $\mathrm{OHCs}$, $\mathrm{ACh}$ indeed activates nonspecific cation channels sensitive to curare. Calcium influx, probably through these ligand-gated channels, secondarily activates a much larger $\mathrm{Ca}^{2+}$-dependent $\mathrm{K}^{+}$current.

Parts of this work have appeared previously in abstract form (Blanchet and Dulon, 1993, 1994a,b; Blanchet et al., 1995).

\section{MATERIALS AND METHODS}

OHC preparation. OHCs were isolated in a previously described manner (Dulon et al., 1990). Briefly, young adult pigmented guinea pigs (weight 
Table 1. Compositions of intracellular solutions, liquid junction potentials $\left(V_{L, J}\right)$, and cell resting membrane potentials $\left(V_{k}\right)$

\begin{tabular}{|c|c|c|c|c|c|c|}
\hline Solution number & $\begin{array}{l}1 \\
\text { KGlu }\end{array}$ & $\begin{array}{l}2 \\
\mathrm{KCl} \\
\end{array}$ & $\begin{array}{l}3 \\
\mathrm{CsCl}\end{array}$ & $\begin{array}{l}4 \\
\text { DM-n }\end{array}$ & $\begin{array}{l}5 \\
\text { BAPTA } 5 \\
\end{array}$ & $\begin{array}{l}6 \\
\text { BAPTA } 10 \\
\end{array}$ \\
\hline Corresponding figures & 1 & 2 & 3 & 4,5 & & $6,7,8$ \\
\hline K-gluconate (mM) & 140 & & & 21 & & 125 \\
\hline $\mathrm{KCl}(\mathrm{mM})$ & 24 & 150 & 50 & 126 & 150 & 20 \\
\hline $\mathrm{K}_{2} \mathrm{SO}_{4}(\mathrm{mM})$ & & & & 10 & & \\
\hline $\mathrm{CsCl}(\mathrm{mm})$ & & & 100 & & & \\
\hline $\mathrm{NaCl}(\mathrm{mM})$ & & 2 & 2 & & & \\
\hline $\mathrm{NaOH}$ & & & & & & 30 \\
\hline $\mathrm{MgSO}_{4}(\mathrm{mM})$ & & & & 2 & 2 & \\
\hline $\mathrm{MgCl}_{2}(\mathrm{mM})$ & 2 & 2 & 2 & & & 2 \\
\hline $\mathrm{CaCl}_{2}(\mathrm{~mm})$ & & & & 1 & & \\
\hline DM-ritrophen (mM) & & & & 5 & & \\
\hline EGTA (mM) & 1.1 & 1.1 & 1.1 & & & \\
\hline BAPTA (mM) & & & & & 5 & 10 \\
\hline D-glucose (mM) & & 10 & 4 & 0.5 & 1 & \\
\hline HEPES (mM) & 5 & 5 & 5 & 5 & 5 & 5 \\
\hline$V_{\mathrm{LJ}}(\mathrm{mV})$ & +11 & -2 & -3 & +2 & -2 & +14 \\
\hline$V_{\mathrm{R}}(\mathrm{mV} ;$ mean $\pm \mathrm{SD})$ & $\begin{array}{l}-63.4 \pm 10.2 \\
n=52\end{array}$ & $\begin{array}{l}-59.1 \pm 8 \\
n=15\end{array}$ & $\begin{array}{l}-33.3 \pm 7.3 \\
n=16\end{array}$ & $\begin{array}{l}-61.1 \pm 9.6 \\
n=47\end{array}$ & $\begin{array}{l}-62.7 \pm 7.6 \\
n=9\end{array}$ & $\begin{array}{l}-64.8 \pm 10.9 \\
n=32\end{array}$ \\
\hline
\end{tabular}

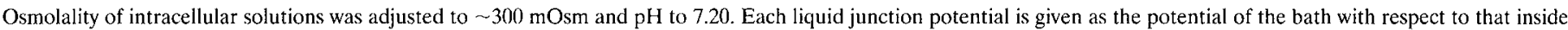
the pipette.

$180-300 \mathrm{gm}$ ) were deeply anesthetized with an intramuscular injection of $0.3 \mathrm{ml}$ of a mixed solution of $2 / 3$ ketamine hydrochlorate $(50 \mathrm{mg} / \mathrm{ml}$; Ketalar, Parke-Davis, Courbevoie, France) and $1 / 3$ xylazine (2\%; Rompun, Bayer, Leverkusen, Germany) before killing. The tympanic bullas were removed and opened in HBSS (in mM: $\mathrm{Car}_{2} \cdot 2 \mathrm{H}_{2} \mathrm{O} 1.25$, glucose 5.55, $\mathrm{MgSO}_{4} 0.81, \mathrm{KH}_{2} \mathrm{PO}_{4} 0.44, \mathrm{NaCl} 136.9, \mathrm{Na}_{2} \quad{ }^{2} \mathrm{O}_{4} 0.34$, and $\mathrm{KCl}$ 5.4; Sigma, St. Louis, MO). Osmolality of that extracellular medium was adjusted to $300 \pm 2 \mathrm{mOsm} / \mathrm{kg} \mathrm{II} \mathrm{I}_{2} \mathrm{O}$ with $\mathrm{NaCl}$, and pII-buffered at 7.40 with $5 \mathrm{~mm}$ HEPES (Sigma) and $\mathrm{NaOH}$. Each turn of the organ of Corti was dissected and transferred into separate $50 \mu \mathrm{l}$ droplets of HBSS containing $0.5 \mathrm{mg} / \mathrm{ml}$ collagenase (type IV, Sigma). After $15 \mathrm{~min}$ of incubation with collagenase, trypsin (type III-S, Sigma) $w^{\prime \cdots c}$ added to the droplets for $5 \mathrm{~min}$ at a final concentration of $300 \mu \mathrm{g} / \mathrm{ml}$. :en the pieces of the organ of Corti were transferred into $50 \mu 1$ droplets of HBSS on the middle of glass coverslips sealed on the perforated bottom of petri dishes. Cells were mechanically dissociated by gentle flux and efflux by means of a Gilson 100 pipette (Gilson Medical Electronics, Villiers-le-Bel, France) and allowed to settle down onto the glass corerslips during $30 \mathrm{~min}$ in a humid chamber. Finally, the petri dishes were filled with 3-4 $\mathrm{ml}$ of HBSS. The morphological criteria that allowed us to distinguish healthy OHCs have been described previously in detail (Dulon et al., 1990, 1991).

Electrophysiological recordings. Patch-clamp recordings were performed in tight-seal whole-cell configuration (Hamill et al., 1981) by means of an Axopatch-1D amplifier and a CV-4 1/100 headstage with a $500 \mathrm{M} \Omega$ feedback resistor (Axon Instruments, Foster City, CA). Output analog signals of the amplifier, filtered with an $80 \mathrm{~dB} /$ decade low-pass Bessel filter with $-3 \mathrm{~dB}$ frequency at $5 \mathrm{kHz}$, were converted to digital signals by a 12-bit acquisition system TL-1/Lab Master (Scientific Solutions, Solon, $\mathrm{OH})$ connected to a $486 \mathrm{DX} 2$ computer. ACh-evoked responses under voltage- or current-clamp conditions were recorded and analyzed with Axotape software (Axon Instruments).

The recording patch pipettes were pulled from borosilicate glass type GC150TF-10 (Clark Electromedical Instruments, Pangbourne, UK) using a Sachs-Flaming micropipette puller (model PC-84, Sutter Instruments, Novato, CA). They were back-filled with various internal solutions (see Table 1) and had resistances ranging from 3 to $6 \mathrm{M} \Omega$. Capacitive currents were electronically compensated, and whole-cell capacitance ranged from 5 to $36 \mathrm{pF}(17.9 \pm 6.8 \mathrm{pF}$; mean $\pm \mathrm{SD} ; n=171)$. Voltage errors attributable to uncompensated series resistance $(17.8 \pm 7.4 \mathrm{M} \Omega$; $n=171)$ and to liquid junction potentials $\left(V_{L_{3}}\right.$; see Table 1$)$ were corrected for during data analysis.

Whole-cell tight-seal recordings were essentially made from OHCs isolated from the second and third turns of the cochlea. As described previously (Santos-Sacchi and Dilger, 1988; Housley and Ashmore, 1992; Eróstegui et al., 1994a), these cells displayed low zero-current potentials immediately after establishment of the whole-cell configuration and reached stable resting potentials $\left(V_{\mathrm{R}}\right.$; see Table 1$)$ within a few minutes

Calcium imaging using Fluo-3. In one set of experiments, calcium imaging was simultaneously conducted with whole-cell recording. The calcium dye Fluo-3 (Molecular Probes, Eugene, OR) was loaded into the cell through the patch-pipette at a concentration of $100 \mu \mathrm{M}$. The fluorescence of Fluo-3 was imaged using a confocal laser scanning microscope (CLSM; Odyssey, Noran Instruments, Middleton, WI) working at video rate $(25 \mathrm{~Hz})$ as described previously (Dulon et al., 1993b, 1994, 1995). The confocal system was attached to a Leitz fluovert inverted microscope (Leitz, Wetzlar, Germany) and was equipped with an argon ion laser and a fluorescein filter cartridge. The laser beam was focused by a $60 \times$ objective lens (Olympus Plan-Apo, numerical aperture 1.4; Olympus Optical, Tokyo, Japan), and fluorescence was reflected by a dichroic mirror to the photomultiplier through a $50 \mu \mathrm{m}$ slit, allowing optical sections of $\sim 1 \mu \mathrm{m}$ thickness. The video detector output was recorded on a tape recorder (U-Matic VO-5800PS, Sony, Tokyo, Japan) and subsequently analyzed using the image processing and analysis system Image-1 (Universal Imaging Corporation, West Chester, PA). Although Fluo-3 fluorescence does not provide quantification of intracellular concentration of $\mathrm{Ca}^{2+}$, in combination with confocal microscopy it does allow determination of temporal and spatial variations of cytosolic free calcium.

Caged-probes experiments. DM-nitrophen (Calbiochem, La Jolla, CA) is a caged-Ca ${ }^{2+}$ chelator for which the $K_{\mathrm{d}}$ for $\mathrm{Ca}^{2+}$ increases after ultraviolet (UV) illumination. Caged-IP ${ }_{3}$ (Calbiochem) is another cagedcompound that rapidly releases active $\mathrm{IP}_{3}$ when exposed to UV irradiation. Experimental protocols were similar to previous studies in which effective photoactivation of caged-probes was controlled (Dulon et al., 1993a, 1994, 1995). Because our internal solutions contained $5 \mathrm{~mm}$ HEPES, we assumed that photolysis of caged-probes did not affect intracellular $\mathrm{pH}$. The light source for flash photolysis was a $100 \mathrm{~W}$ mercury arc lamp (HBO 100W/2, Osram, Berlin, Germany). The output of the limin was focused to the cells throught a $60 \times$ objective lens via the epi-illumination pathway from the rear port of the inverted microscope. The output of the mercury lamp was filtered through a filter cube A (Leitz) for excitation at $340-380 \mathrm{~nm}$. The duration of the UV exposure $(20-200 \mathrm{msec})$ was controlled with a Vincent Associates Uniblitz electrical shutter (Rochester, NY) mounted in front of the lamp housing. To avoid mechanical vibrations induced by the shutter, the latter was not physically connected to the microscope. The UV flashes were generally 


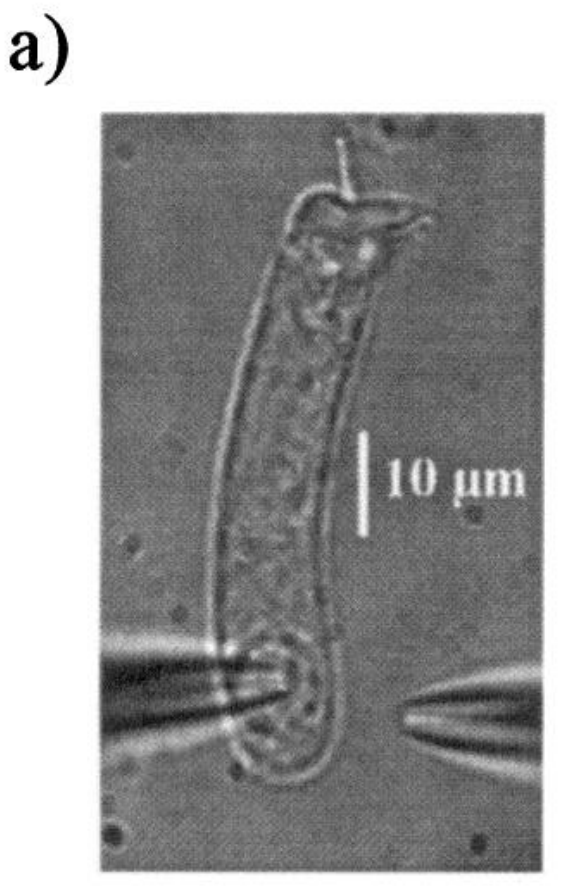

b)
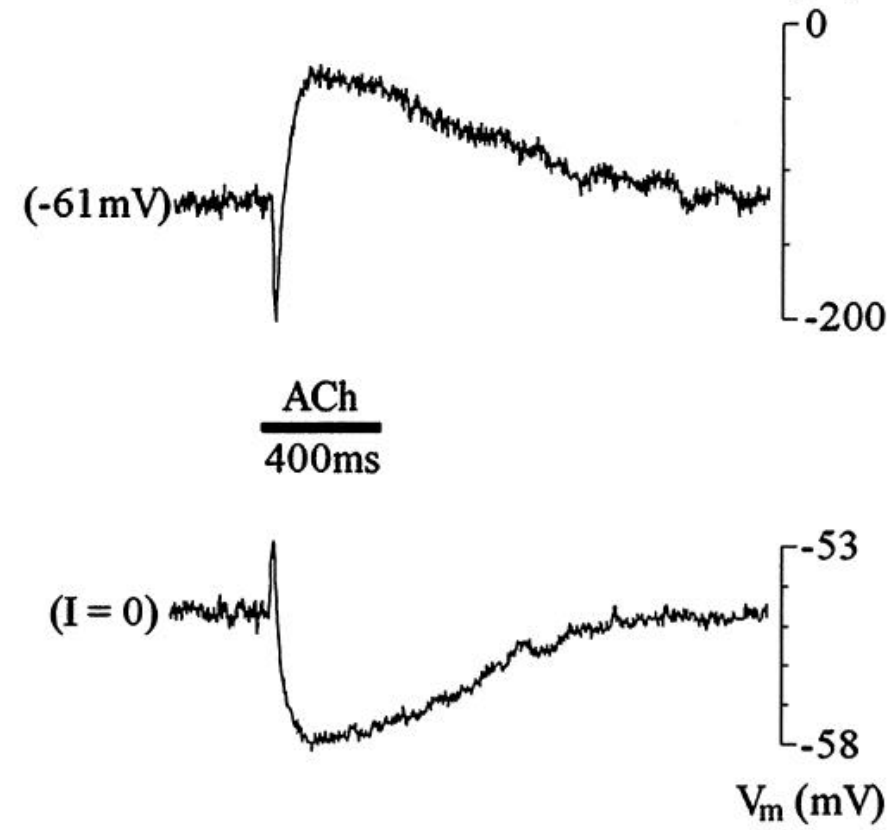

Figure 1. The biphasic nature of OHC response to ACh. $a$, Photomicrograph of a patch-clamped OHC. OHCs were usually patched in the nuclear region or below, and $\mathrm{ACh}$ was puff-applied toward the base. $b$, Current and voltage responses to ACh (100 $\mu \mathrm{M})$ of another patch-clamped OHC. Top trace, Under voltage clamp at $-61 \mathrm{mV}, \mathrm{ACh}$ induced a long-lasting outward current preceded by an early inward current. Bottom trace, Under current clamp at resting membrane potential $(-54 \mathrm{mV}), \mathrm{ACh}$ produced a long-lasting hyperpolarization preceded by a brief depolarization. The cell was dialyzed with the "KGlu" solution 1.

evoked $>3$ min after establishment of whole-cell configuration, thereby allowing caged-probes enough time to dialyze into the cell. We determined that, in the absence of caged-probes, our brief UV illuminations had no effect either on the holding current or on the ACh-induced current.

Drugs and test solution applications. Isolated OHCs were maintained in HBSS extracellular medium in all experiments. ACh-containing solutions were applied extracellularly by using a pressure puff ejector (Picospritzer II, General Valve, Fairfield, NJ) via a glass pipette. These puffer pipettes were pulled similarly to the recording patch pipettes and were held $\sim 10$ $\mu \mathrm{m}$ away from the base of the cells. The delay for drugs to reach the cell ranged from 5 to $50 \mathrm{msec}$ as estimated by either junction potential change or cell depolarization induced by high $\mathrm{K}^{+}$solutions. Current or voltage responses to high $\mathrm{K}^{+}$solutions were found stable until the offset of the puff and from one stimulation to the next. We assume, therefore that in each experiment the puffer application was constant over time and that no mixing between test and bath solutions occurred with time of application. However, because the cells were immersed in a large volume of culture medium (3-4 ml), the small amount of drug applied to the cells can be considered to be rapidly diluted after the offset of pressure application. ACh was freshly diluted at a final concentration of 100 or 200 $\mu \mathrm{M}$, doses that have been shown to provoke maximum responses (Housley and Ashmore, 1991). Charybdotoxin (1.2 $\mu \mathrm{M}$; Latoxan, Rosans, France) and tetraethylammonium chloride (TEA; $10 \mathrm{~mm}$ ) were applied similarly to ACh.

The ACh antagonist D-tubocurarine (D-TC) was freshly diluted in HBSS at a final concentration of $10 \mu \mathrm{M}$ and was applied by gravity using a U-tubing system, which allowed the change of extracellular medium surrounding the recorded cell within $500 \mathrm{msec}$. Particular care was taken to avoid mechanical displacement of the recorded OHCs during application of test solutions. Cell and puff pipette positions were continuously controlled throughout experiments by means of a charge-coupled device video camera (VCB-3512P, Sanyo Electric, Tokyo, Japan), except during fluorescent measurements. All chemical reagents were purchased from Sigma unless stated otherwise. All of the experiments were performed at room temperature $\left(20-22^{\circ} \mathrm{C}\right)$.

\section{RESULTS}

\section{Response of OHCs to ACh}

\section{Current and voltage response}

Pressure-puff application of ACh (100-200 $\mu \mathrm{M})$ activated a hyperpolarizing current with an average delay of $30 \mathrm{msec}$ (from 10 to $140 \mathrm{msec}$ ) in 109 OHCs loaded with any of solutions $1-4$ (see Table 1). Interestingly, the hyperpolarizing current was preceded by an early depolarizing current in some records ( $n=35$ cells; Fig. 1). This biphasic nature of the ACh-induced response could be observed only if the puff pipette was placed $<15 \mu \mathrm{m}$ away from the base of the cells and particularly at membrane potentials close to the reversal potential of the ACh-induced hyperpolarizing current $\left(E_{\text {rev }}\right.$; see Fig. 2). When using the KGlu intracellular solution $1, E_{\text {rev }}$ occurred at $-73.4 \pm 2.2 \mathrm{mV}$ (mean $\pm \mathrm{SD} ; n=12$ cells). In those conditions, the calculated equilibrium potentials for potassium $\left(E_{\mathrm{K}}\right)$ and chloride $\left(E_{\mathrm{Cl}}\right)$ were -84 and $-42 \mathrm{mV}$, respectively. When using the $\mathrm{KCl}$ intracellular solution 2 , the ACh-induced hyperpolarizing current reversed in sign at $-70.4 \pm$ $2.5 \mathrm{mV}$ (mean $\pm \mathrm{SD} ; n=7$ cells; Fig. 2 ) and $E_{\mathrm{K}}$ and $E_{\mathrm{Cl}}$ were -82 and $+1 \mathrm{mV}$, respectively. Otherwise, when $E_{\mathrm{K}}$ was set to $-54 \mathrm{mV}$ using the $\mathrm{CsCl}$ intracellular solution $3, E_{\mathrm{rev}}$ was found at $-42.2 \pm$ $2.6 \mathrm{mV}$ (mean $\pm \mathrm{SD} ; n=7$ cells; see Fig. 3 ). This indicates that, in $\mathrm{OHCs}, \mathrm{K}^{+}$ions were the major charge carriers of the AChinduced hyperpolarizing current, whereas chloride ions seemed not to be involved. The positive shift of $E_{\mathrm{rev}}$ from $E_{\mathrm{K}}$ probably arose from the contribution of the underlying early depolarizing current.

\section{Current-voltage (I-V) relationship of the ACh-evoked current}

Membrane currents elicited by $\mathrm{ACh}$ were studied as a function of holding membrane potential $\left(V_{\mathrm{hr}}\right)$ with $\mathrm{CsCl}$ internal solution 3 , 
a)

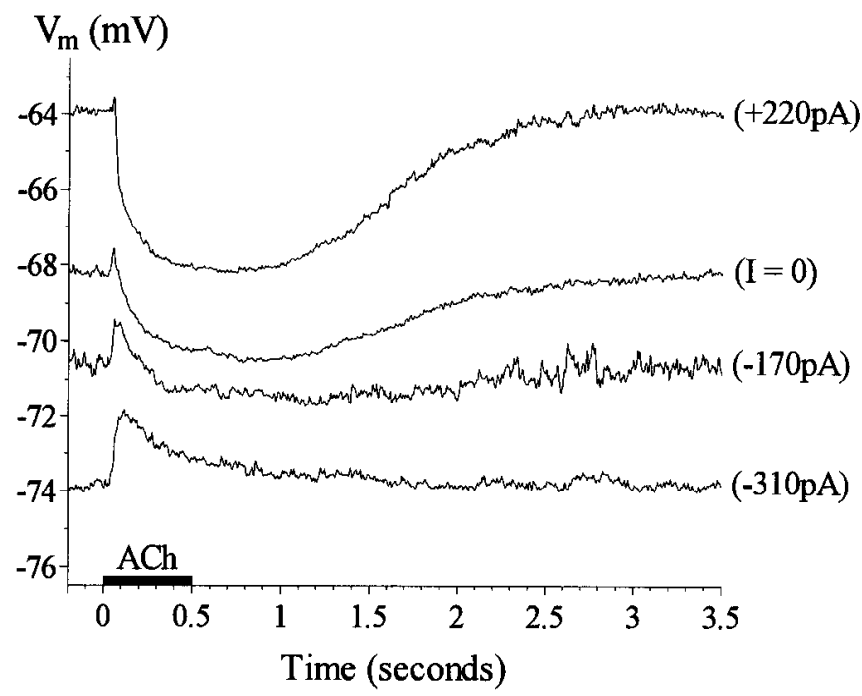

b)

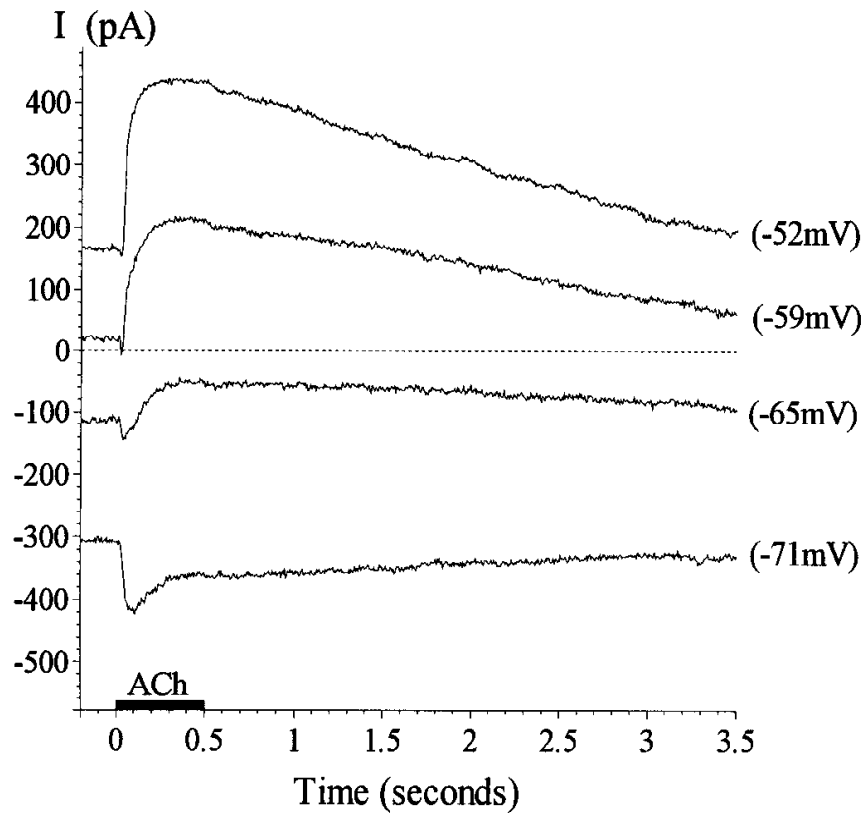

Figure 2. The ACh-induced response is carried mainly by $\mathrm{K}^{+}$ions. Current and voltage responses to ACh $(100 \mu \mathrm{M})$ reversed in sign near the calculated $\mathrm{K}^{+}$equilibrium potential $\left(E_{\mathrm{K}}=-82 \mathrm{mV}\right)$. $a$, Voltage responses to $\mathrm{ACh}$ of an $\mathrm{OHC}$ injected with the listed clamping currents. Note that the initial depolarization was more evident near the reversal potential $\left(E_{\mathrm{rcv}}=-72 \mathrm{mV}\right.$ in this cell). $b$, Current responses to ACh of another $\mathrm{OHC}$ clamped at the listed holding membrane potentials. Note that the early inward current was more largely unmasked near $E_{\mathrm{rev}}(-68 \mathrm{mV}$ in this cell). Both $\mathrm{OHCs}$ were loaded with the $\mathrm{KCl}$ solution 2 .

which was found to allow extended recordings at positive membrane potentials (Fig. 3). In the voltage range of -65 to $-5 \mathrm{mV}$, ACh-induced current varied quite linearly and reversed in sign near $E_{\mathrm{K}}=-54 \mathrm{mV}\left(E_{\mathrm{rev}}=-47 \mathrm{mV}\right)$ as expected for a $\mathrm{K}^{+}$ current (ACh-induced current was clearly biphasic at $-46,-41$, and $-37 \mathrm{mV}$, and peak amplitude was then measured on the late outward current). Between $V_{\mathrm{hr}}=-5$ and $+20 \mathrm{mV}$, ACh-induced current strongly diminished in amplitude and its rate of rise a)
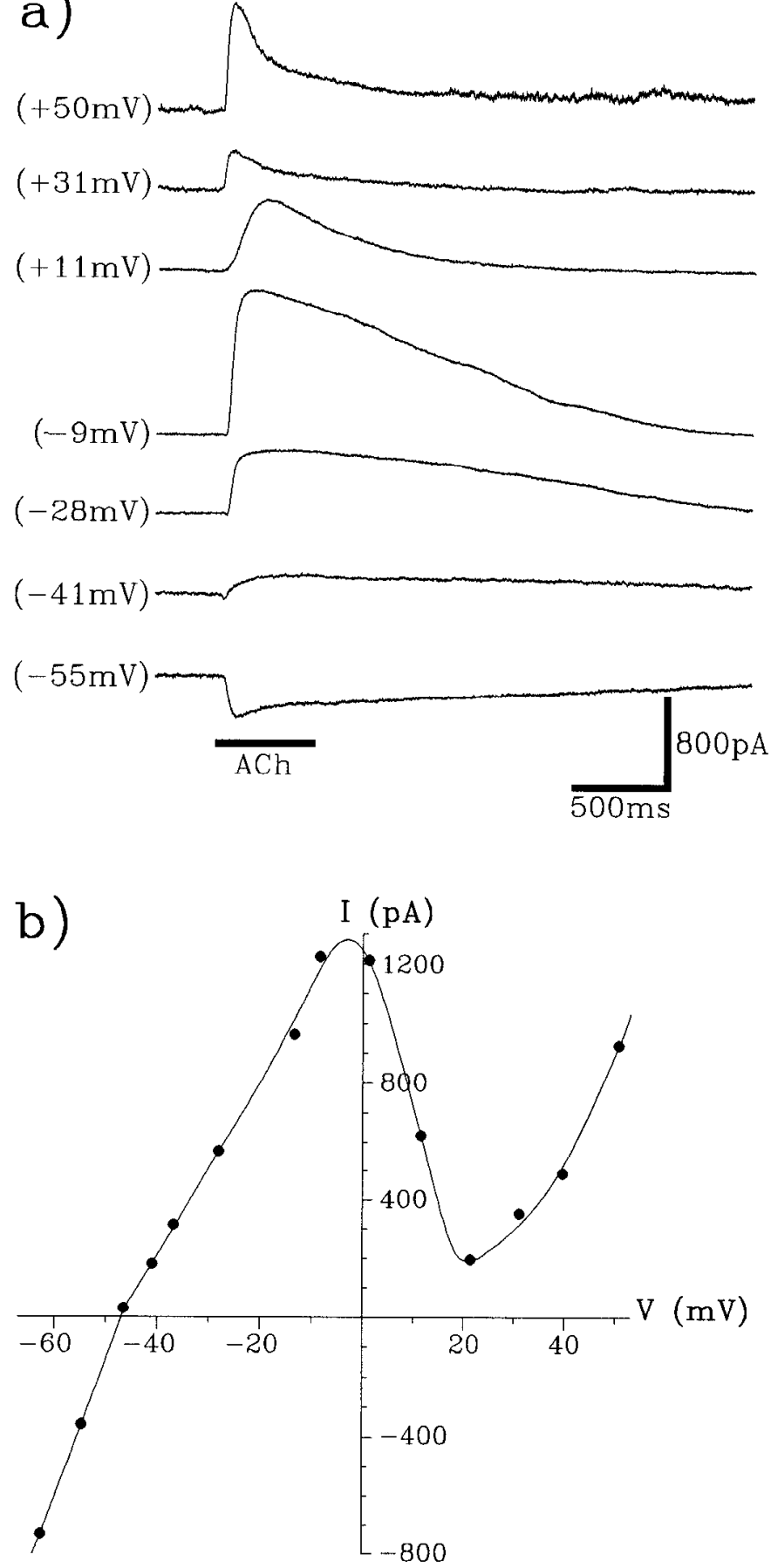

Figure 3. The $I-V$ relationship of the ACh-induced current displays an $\mathrm{N}$-shape. ACh-induced current was examined as a function of membrane potential in one $\mathrm{OHC}$ loaded with internal $\mathrm{CsCl}$ solution 3. $a$, Currents evoked by ACh at the listed membrane potentials. Records are displaced vertically from one another for clarity. $b$, Peak amplitude of ACh-evoked currents in $a$, and others are plotted as a function of membrane potential. The smooth curve was fit by eye.

slowed (see Fig. $3 a,+11 m V$ ). Additionally, we noticed that as the cell was depolarized from -65 to $+20 \mathrm{mV}$, the ACh-induced current deactivated faster after the puff stop. Finally, when $V_{\mathrm{hr}}$ was positive to $+20 \mathrm{mV}$, ACh-induced current grew again with a fast rate of rise and desensitized strongly during $\mathrm{ACh}$ application. As a result, the $I-V$ relationship of the ACh-induced current 
displayed an $\mathrm{N}$-shape. Such an $I-V$ relationship was clearly observed in 5 cells loaded with $\mathrm{CsCl}$ solution 3, peak current amplitudes reaching a maximum between -15 and $0 \mathrm{mV}$ and a minimum between +10 and $+25 \mathrm{mV}$. Furthermore, 4 OHCs dialyzed with KGlu solution 1 (see Table 1), but that could not be tested for extended positive membrane polentials, showed $I-V$ relationships with a bell shape. The $\mathrm{N}$-shaped $I-V$ relationship of the ACh-induced current is reminiscent of that displayed by some $\mathrm{Ca}^{2+}$-dependent $\mathrm{K}^{+}$currents activated secondarily to $\mathrm{Ca}^{2+}$ influx, the decrease in amplitude of $\mathrm{K}^{+}$current at depolarized membrane potentials proceeding from the diminishing driving force on $\mathrm{Ca}^{2+}$ (Meech and Standen, 1975; Fuchs and Murrow, 1992a; Housley and Ashmore, 1992).

These observations have led us to examine the $\mathrm{Ca}^{2+}$ dependence of the late-hyperpolarizing $\mathrm{K}^{+}$current activated by $\mathrm{ACh}$ in $\mathrm{OHCs}\left(I_{\mathrm{K}(\mathrm{ACh})}\right)$.

\section{Involvement of $\mathrm{Ca}^{2+}$ in the response to $\mathrm{ACh}$ Calcium imaging}

In a first set of experiments, we combined whole-cell patch-clamp recording with calcium imaging by means of the fluorescent calcium probe Fluo-3 and CLSM. Fluo-3 was added to the DM-n solution 4 (see Table 1) at a final concentration of $100 \mu \mathrm{M}$ and thus dialyzed into the cell by means of the patch pipette. ACh (200 $\mu \mathrm{M})$ was applied onto $10 \mathrm{OHCs}$ while Fluo-3 fluorescence and ionic currents were simultaneously recorded. Neither current nor $\mathrm{Ca}^{2+}$ responses were elicited in 4 cells. On the other hand, in 5 out of the 6 other cells that displayed $I_{\mathrm{K}(\mathrm{ACh})}$, a concomitant $\mathrm{Ca}^{2+}$ response was clearly observed (Fig. 4). However, rises in intracellular $\mathrm{Ca}^{2+}$ appeared small and restricted to the synaptic region of OHCs as determined by measuring Fluo-3 fluorescence in various windows $\left(16-36 \mu \mathrm{m}^{2}\right)$ placed over different regions of the cells (Fig. $4 a, b$ ). Otherwise, we used as a positive control the caged$\mathrm{Ca}^{2+}$ chelator DM-nitrophen, for which the $K_{\mathrm{d}}$ for $\mathrm{Ca}^{2+}$ strongly increases after UV illumination (Kaplan and Ellis-Davies, 1988; Dulon et al., 1994, 1995). UV photolysis of intracellularly dialyzed DM-nitrophen (see DM-n solution 4, Table 1) triggered simultaneously a hyperpolarizing current and $\mathrm{a} \mathrm{Ca}^{2+}$ response in the 5 OHCs tested (data not shown). Unlike the ACh-evoked $\mathrm{Ca}^{2+}$ response, the $\mathrm{Ca}^{2+}$ jump after DM-nitrophen photolysis was large (in the micromolar range) and concerned the whole cell, as described previously (Dulon et al., 1994, 1995). In one OHC that could be successively stimulated with $\mathrm{ACh}$ and DM-nitrophen photolysis, the $\mathrm{ACh}$-induced $\mathrm{Ca}^{2+}$ response revealed by Fluo-3 fluorescence was clearly small and restricted compared with that induced by DM-nitrophen photolysis (data not shown).

In separate experiments, we tested the possible involvement of $\mathrm{Ca}^{2+}$ release from intracellular stores via the $\mathrm{IP}_{3}$ pathway in the ACh response, as suggested by Kakehata et al. (1993). For that purpose, we loaded cells, via the patch pipette, with caged-IP $(20-50 \mu \mathrm{M})$, which releases rapidly active $\mathrm{IP}_{3}$ after $\mathrm{UV}$ photolysis (Walker et al., 1989). Intracellular photoreleased $\mathbf{I P}_{3}$ did not trigger any detectable $\mathrm{Ca}^{2+}$ response, current activation $(n=12$ cclls), or any modification of $I_{\mathrm{K} \text { (ACh) }}(n=2$ cclls). As positive controls, large, transient rises in intracellular free $\mathrm{Ca}^{2+}$ have been recorded in Deiters' supporting cells subsequent to $\mathrm{IP}_{3}$ photorelease in similar experiments (Dulon et al., 1993a).

\section{C $a^{2+}$ photorelease from DM-nitrophen}

The ability of $\mathrm{Ca}^{2+}$ photorelease to activate $\mathrm{Ca}^{2+}$-sensitive channels (Kaplan and Ellis-Davies, 1988; Lancaster and Zucker, 1994; Dulon et al., 1995) was used to study more directly the $\mathrm{Ca}^{2+}$
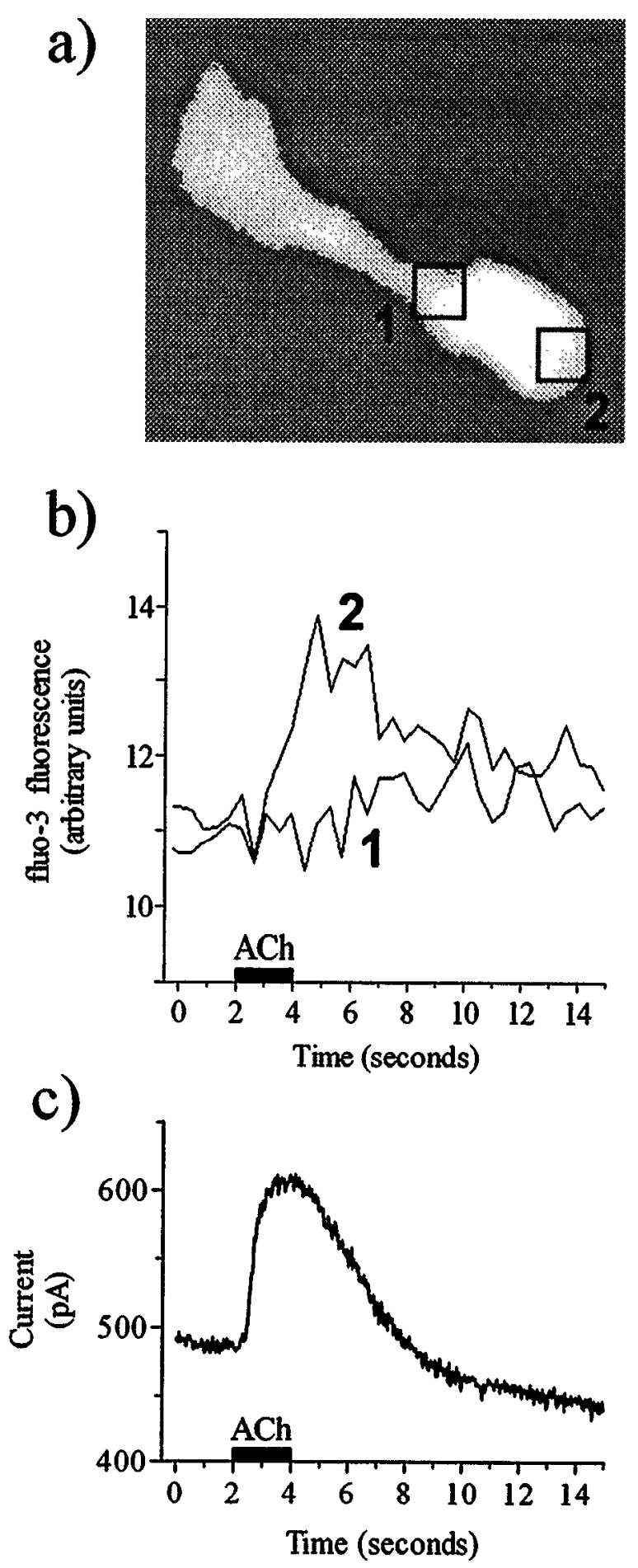

Figure 4. ACh triggers a localized calcium response concomitant to current activation. The fluorescent probe Fluo-3 $(100 \mu \mathrm{M})$ was added to DM-n solution 4 and dialyzed into the cell via the patch pipette. $a$, Optically sliced image ( $\sim 1 \mu \mathrm{m}$ thick) of the Fluo-3 fluorescence from a $40-\mu \mathrm{m}$-long $\mathrm{OHC}$. Changes in fluorescence were monitored in windows 1 and $2\left(4 \times 4 \mu \mathrm{m}^{2}\right)$ situated at the basal pole of the cell just above and below the nucleus, respectively. $b$, ACh $(200 \mu \mathrm{M}, 2 \mathrm{sec})$ induced a small $\mathrm{Ca}^{2+}$ responsc restricted to the synaptic region of the cell (window 2 in $a$ ). Changes in intracellular free $\mathrm{Ca}^{2+}$ level were monitored and averaged every $450 \mathrm{msec}$ in windows 1 and 2 using the fluorescence of Fluo-3 (expressed here in arbitrary units). $c$, Simultaneously in the same cell, ACh triggered an outward current $\left(V_{\mathrm{hr}}=-50 \mathrm{mV}\right)$. To avoid fluorescence artifacts caused by cell displacement, the puff pipette was placed $\sim 30 \mu \mathrm{m}$ away from the cell base. 


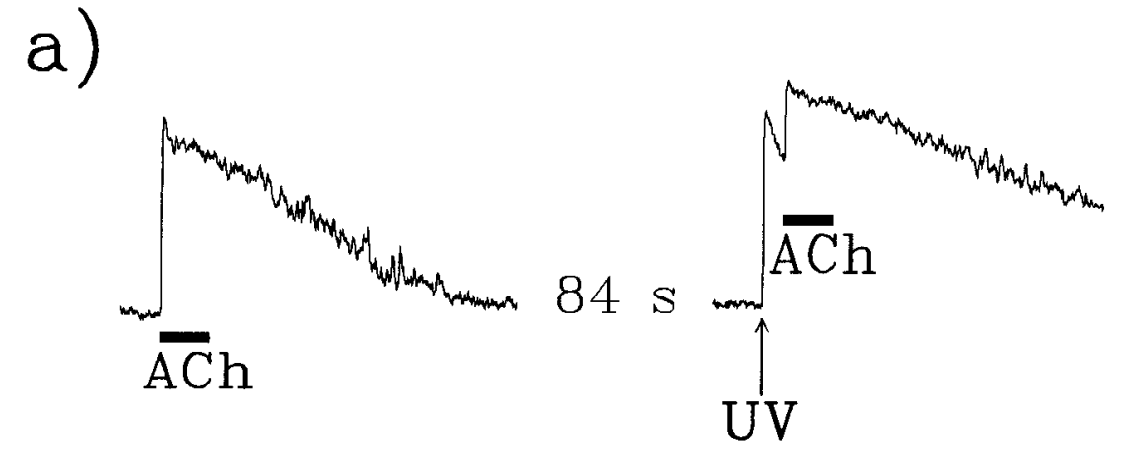

$I=0$

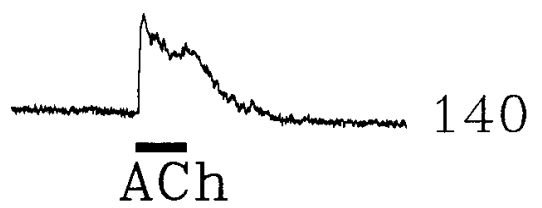

$I=0$

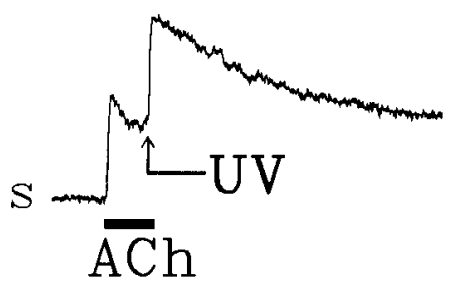

189

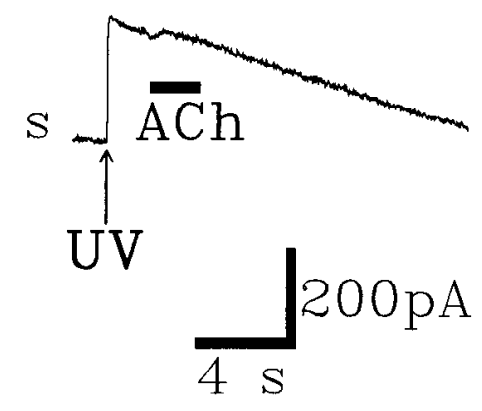

Figure 5. Relationships between the ACh-induced current and the current activated by $\mathrm{Ca}^{2+}$ photorelease. The caged-Ca ${ }^{2+}$ chelator DM-nitrophen, for which the $K_{\mathrm{d}}$ for $\mathrm{Ca}^{2+}$ increases on UV photolysis, was used as the calcium buffer of internal DM-n solution 4. $a$, The ACh-induced current was not additive to the $\mathrm{Ca}^{2+}$-activated $\mathrm{K}^{+}$current triggered by DM-nitrophen photolysis. $V_{\mathrm{hr}}=-39 \mathrm{mV} ; \mathrm{ACh}: 200 \mu \mathrm{M}, 2 \mathrm{sec}$; UV: $20 \mathrm{msec}$. The three traces were recorded successively and spaced by 84 and $115 \mathrm{sec}$ as indicated. $b$, The $\mathrm{Ca}^{2+}$-activated $\mathrm{K}^{+}$current triggered by DM-nitrophen photolysis was additive to the ACh-induced current. $V_{\mathrm{hr}}=-41 \mathrm{mV}$; ACh: $200 \mu \mathrm{M}, 2 \mathrm{sec}$; UV: $100 \mathrm{msec}$. The three traces were recorded successively and spaced by 140 and 189 sec as indicated. $a$ and $b$ were obtained from two different OHCs. Dotted lines indicate zero current level.

dependence of the cholinergic response. From 47 OHCs loaded with DM-n solution 4 (see Table 1), UV photolysis of DMnitrophen was performed in 31 cells and triggered a hyperpolarizing current in all of them, even if they were not responsive to ACh. This photoactivated current appeared to be carried mainly by $\mathrm{K}^{+}$ions $\left(E_{\mathrm{rev}}=-76 \pm 4 \mathrm{mV}\right.$; mean $\pm \mathrm{SD} ; n=7$ cells; $E_{\mathrm{K}}=$ $-84 \mathrm{mV})$ and was sensitive to both TEA ( $10 \mathrm{mM} ; n=5$ cells $)$ and charybdotoxin ( $1.2 \mu \mathrm{M} ; n=2$ cells; data not shown). After these observations, we studied the relations between $I_{\mathrm{K}(\mathrm{ACh})}$ and $\mathrm{Ca}^{2+}$. activated $\mathrm{K}^{+}$current triggered by $\mathrm{Ca}^{2+}$ photorelease $\left(I_{\mathrm{K}(\mathrm{Ca})}\right)(\mathrm{Fig}$. $5)$. For that purpose, we used short UV flashes $(20-200 \mathrm{msec})$ to allow recovery of responses, and we applied ACh at $200 \mu \mathrm{M}$, which is above the concentration required for maximum response (Housley and Ashmore, 1991). When ACh was putfed during the photoactivated $I_{\mathrm{K}(\mathrm{Ca})}, I_{\mathrm{K}(\mathrm{ACh})}$ was strongly reduced compared with controls (Fig. 5a). This bchavior was clcarly obscrved in 4 cells. Two hypotheses, which do not exclude each other, could explain $I_{\mathrm{K}(\mathrm{ACh})}$ reduction: (1) most of ACh-related $\mathrm{K}^{+}$channels were already activated by the $\mathrm{Ca}^{2+}$ jump before $\mathrm{ACh}$ application; and/or (2) intracellular $\mathrm{Ca}^{2+}$ exerts an inhibitory effect on the $\mathrm{ACh}$ response.

Within the framework of experiments with DM-nitrophen, we also tested the effect of a $\mathrm{Ca}^{2+}$ photorelease during $I_{\mathrm{K} \text { (ACh) }}$ activation (Fig. $5 b$ ). It then appeared that UV flash triggered a large outward $I_{\mathrm{K} \text { (Ca) }}$ additive to $I_{\mathrm{K} \text { (ACh) }}(n=6$ cells). This suggests that $\mathrm{ACh}$ could not activate all of the $\mathrm{Ca}^{2+}$-activated $\mathrm{K}^{+}$ channels of OHCs.

\section{Prevention of $\mathbf{I}_{K(A C h)}$ activation}

Two other methods were used to verify the activator role of $\mathrm{Ca}^{2+}$ in the cholinergic response. First, when $\mathrm{ACh}$ was applied to OHCs in a $\mathrm{Ca}^{2+}$-free saline (substituted with $\mathrm{Mg}^{2+}$ ), $I_{\mathrm{K}(\mathrm{ACh})}$ was inhibited compared with pre- and post-controls in normal external solution ( $n=4$ cells; data not shown). In these conditions, no inward current was unmasked, as described previously by Housley and Ashmore (1991). Second, we used the fast $\mathrm{Ca}^{2+}$ buffer bis(2aminophenoxy)ethane- $N, N, N^{\prime}, N^{\prime}$-tetra-acetic acid (BAPTA) in place of EGTA in the internal solution. BAPTA has more rapid binding kinetics with $\mathrm{Ca}^{2+}$ than does EGTA (Tsien, 1980) and was reported to prevent activation of $I_{\mathrm{K}(\mathrm{ACh})}$ in avian short hair cells (Fuchs and Murrow, 1992a). When OHCs were loaded with 5 mм BAPTA (solution 5, Table 1), activation of $I_{\mathrm{K}(\mathrm{ACl})}$ was not prevented ( $n=9$ cells), but the early inward current preceding $I_{\mathrm{K}(\mathrm{ACh})}$ was more frequently recorded than with any of the solutions 1-4. However, when OHCs were dialyzed with the internal solution 6 containing $10 \mathrm{~mm}$ BAPTA (see Table 1), activation of $I_{\mathrm{K} \text { (ACh) }}$ was prevented in 30 of 32 responsive cells, confirming that $I_{\mathrm{K}(\mathrm{ACh})}$ flows through $\mathrm{Ca}^{2+}$-activated $\mathrm{K}^{+}$channels. 


\section{Nature of the early current}

\section{Isolation of the early current}

Loading OHCs with BAPTA 10 solution 6 prevented $I_{\mathrm{k}(\mathrm{ACh})}$ and, interestingly, allowed the examination of the early current activated by $\mathrm{ACh}\left(I_{\mathrm{e}(\mathrm{ACh})}\right)$ in isolation (Fig. 6-8). Contrary to $I_{\mathrm{K}(\mathrm{ACh})}$, the early current displayed no rundown but displayed long-lasting desensitization. Indeed, $\sim 1 \mathrm{~min}$ between two successive applications of $\mathrm{ACh}(100 \mu \mathrm{M})$ was necessary to allow complete recovery of $I_{\mathrm{e}(\mathrm{ACh})}$. Figure $6 a$ shows that $I_{\mathrm{e}(\mathrm{ACh})}$ activated rapidly and desensitized strongly during $100 \mu \mathrm{M}$ ACh application regardless of the holding membrane potential. When the puff pipette was placed $\sim 10 \mu \mathrm{m}$ away from the base of various OHCs, $I_{\mathrm{e}(\mathrm{ACh})}$ activated within 5-60 msec after the puff start. Because the time required for $\mathrm{ACh}$ to reach its receptor ranged at least from 5 to 50 msec (as estimated in other experiments by measuring the delay of either junction potential change or cell depolarizing current provoked by puffing high $\mathrm{K}^{+}$solutions), the intrinsic delay of $\left.I_{\mathrm{e}} \mathrm{ACh}\right)$ activation should be in the millisecond range, suggesting that the $\mathrm{ACh}$ receptor (AChR) is ionotropic. Furthermore, $I_{\mathrm{e}(\mathrm{ACh})}$ could be recorded more than $1 \mathrm{hr}$ after establishment of the whole-cell configuration, even if the cell resting membrane potential was positive to $-20 \mathrm{mV}$.

\section{I-V relationship}

The early current was studied as a function of membrane potential (Fig. 6a). The $I-V$ relationship revealed that $I_{\mathrm{e}(\mathrm{ACh})}$ reversed at $-15.6 \pm 2.6 \mathrm{mV}$ (mean $\pm \mathrm{SD} ; n=5$ cells; Fig. $6 b$ ). This suggested that $I_{\mathrm{e}(\mathrm{ACh})}$ flowed through nonspecific cation channels, because $E_{\text {rev }}$ was nearly as distant from the equilibrium potentials for $\mathrm{K}^{+}$ and $\mathrm{Na}^{+}\left(E_{\mathrm{K}}=-81 ; E_{\mathrm{Na}}=+39 \mathrm{mV}\right.$; a chloride channel must be excluded because equilibrium potential for $\mathrm{Cl}^{-}$was set to -46 $\mathrm{mV})$. Another interesting feature of the $I-V$ curve shown in Figure $6 b$ was its marked outward rectification at positive membrane potential ( $n=5$ cells). In addition, an inward rectification for $V_{\mathrm{hr}}$ negative to $-60 \mathrm{mV}$ was observed ( $n=5$ cells).

We also studied $I_{\mathrm{e}(\mathrm{ACh})}$ as a function of the puff pipette position (data not shown). As described for $I_{\mathrm{K}(\mathrm{ACh})}$ (Housley and Ashmore, 1991; Housley et al., 1992), we observed that the magnitude of $I_{\mathrm{e}(\mathrm{ACh})}$ diminished and its latency increased as the puff pipette was moved along the cell from the base to the apex. That observation is in agreement with the position of efferent endings and the localization of AChRs (Fex and Altschuler, 1986; Canlon et al., 1989; Plinkert et al., 1990). Otherwise, as the puff pipette was moved away but kept directed toward the base of the cell, $I_{\mathrm{e}(\mathrm{ACh})}$ was also reduced in amplitude and, interestingly, its desensitization during $\mathrm{ACh}$ application became weaker. These features suggest that most of the AChRs were activated at the same time, but desensitized rapidly, when $\mathrm{ACh}$ was applied $\sim 10 \mu \mathrm{m}$ away from the cell base.

\section{Inhibition of the early current}

To ensure that $I_{\mathrm{e}(\mathrm{ACh})}$ was of a nicotinic nature, we studied its sensitivity to D-TC. When ACh $(100 \mu \mathrm{M})$ was pressure-puffed during D-TC $(10 \mu \mathrm{M})$ perfusion via a U-tubing system, $I_{\mathrm{e}(\mathrm{ACh})}$ was reversibly blocked (Fig. 7). Such complete inhibition was clearly observed in three different OHCs, even at positive membrane potentials.

In another set of experiments, we studied the effect of the absence of extracellular $\mathrm{Ca}^{2+}$ on $I_{\mathrm{e}(\mathrm{ACh})}$. For that purpose, $\mathrm{ACh}$ $(100 \mu \mathrm{M})$ was puff-applied either with a normal saline $(1.25 \mathrm{~mm}$ $\mathrm{Ca}^{2+}$ ) or with a $\mathrm{Ca}^{2+}$-free saline (substituted with $\mathrm{Mg}^{2+}$ ) while the bath medium was kept normal. The equilibrium potential for
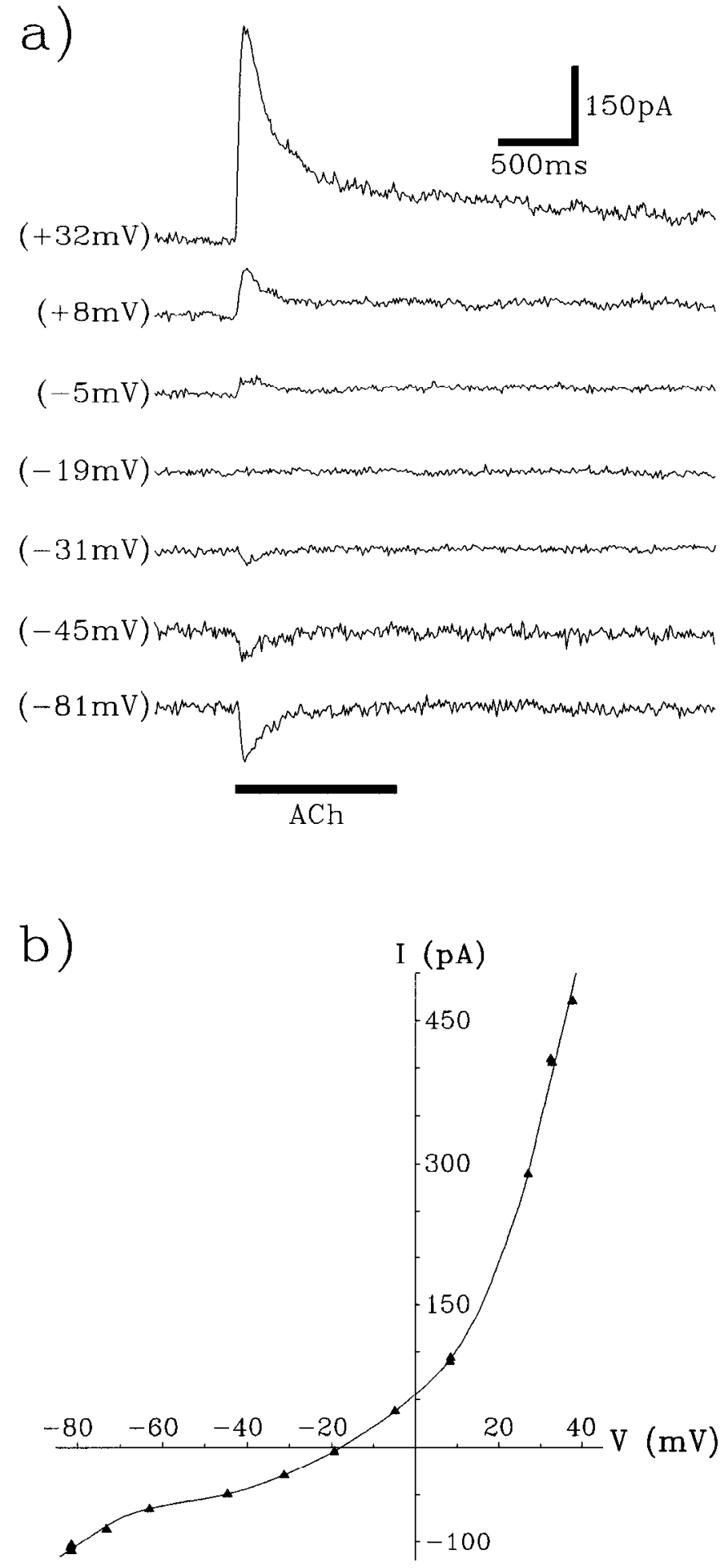

Figure 6. I-V relationship of the ACh-evoked current in a $10 \mathrm{~mm}$ BAPTA-loaded OHC. $a$, ACh-evoked currents at listed membrane potentials. Records are displaced vertically from one another for clarity. $b$, Peak amplitude of ACh-evoked currents are plotted as a function of membrane potential. The smooth curve was fit by eye. Reversal potential occurred at $-18 \mathrm{mV}$ in this cell. Internal solution 6; ACh: $100 \mu \mathrm{M}$.

$\mathrm{Ca}^{2+}$ was about $+180 \mathrm{mV}$ with normal saline and about $+90 \mathrm{mV}$ with $\mathrm{Ca}^{2+}$-free saline (assuming only $1 \mu \mathrm{M}$ contaminant $\mathrm{Ca}^{2+}$ ). As shown in Figure $8, I_{\mathrm{e}} \mathrm{ACh}$ ) was reversibly and strongly reduced when $\mathrm{ACh}$ was applied with $\mathrm{Ca}^{2+}$-free saline ( $n=3$ cells). 

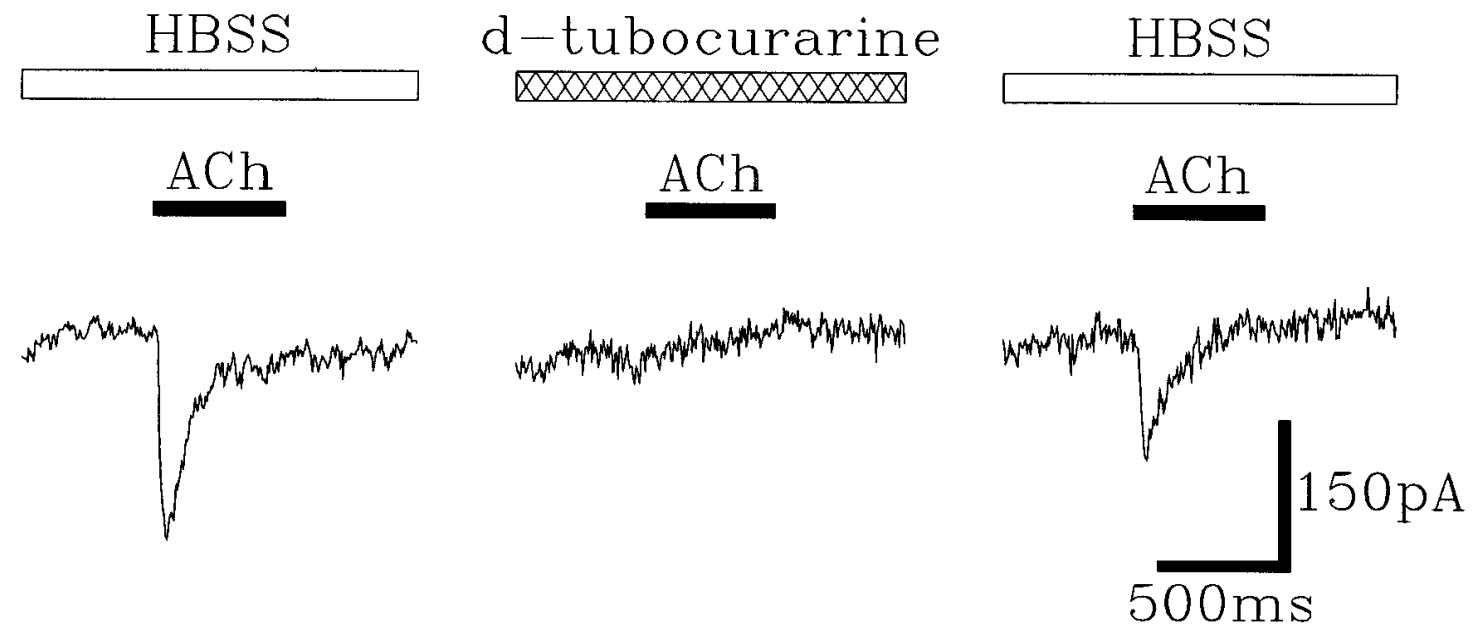

Figure 7. D-TC reversibly inhibits the ACh-evoked early current. The cell was loaded with the internal BAPTA 10 solution 6 . The early current was reversibly inhibited when ACh $(100 \mu \mathrm{M})$ was puff-applied during exposure to $10 \mu \mathrm{M} \mathrm{D}-\mathrm{TC}\left(V_{\mathrm{hr}}=-81 \mathrm{mV}\right)$. HBSS with or without D-TC was perfused via a U-tubing system during each recording as indicated by the upper bars.

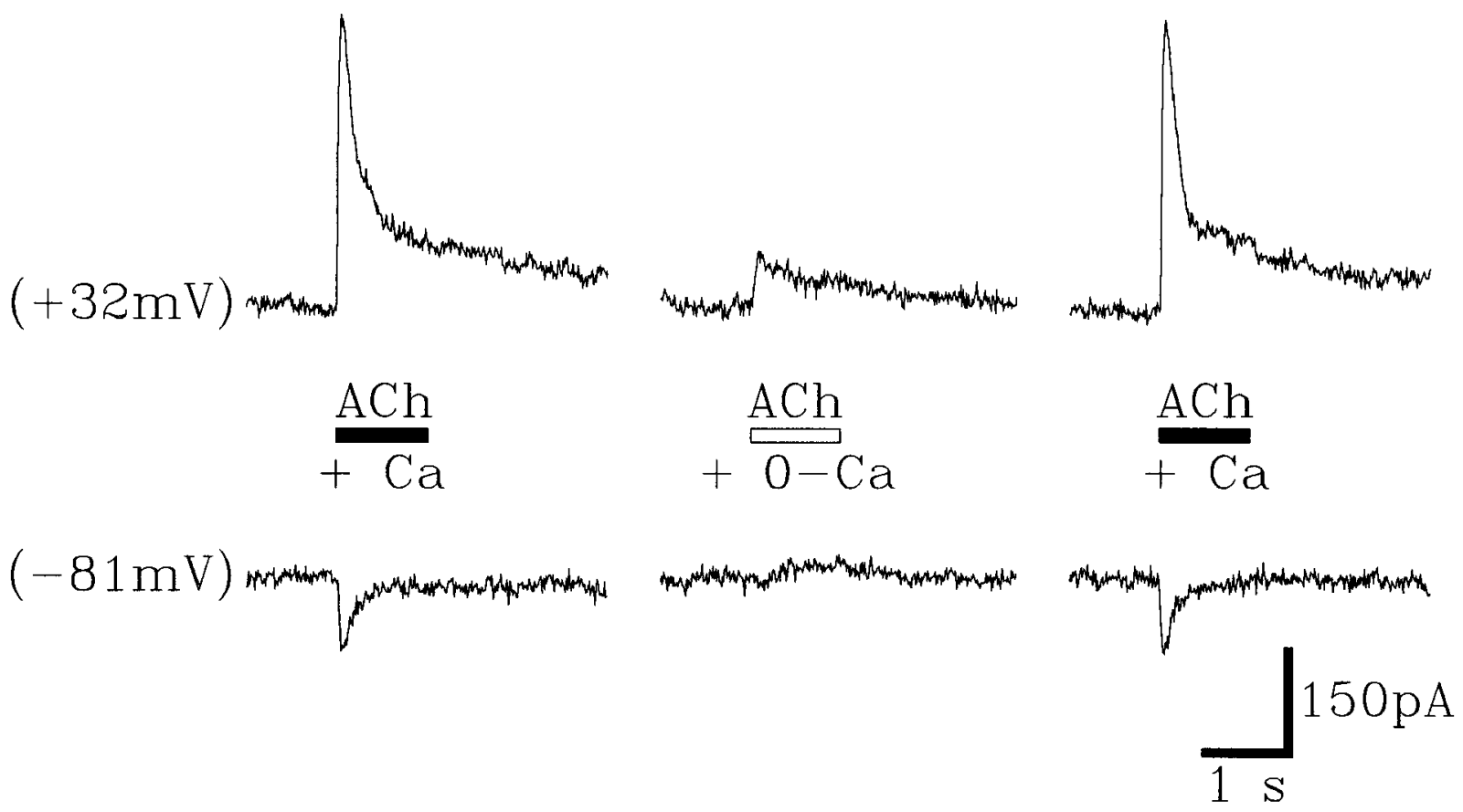

Figure 8. Activation of the early current requires extracellular $\mathrm{Ca}^{2+}$. The cell was loaded with BAPTA 10 solution 6 and bathed in HBSS. For the second ACh application, at either +32 or $-81 \mathrm{mV}, \mathrm{Ca}^{2+}$ was substituted with $\mathrm{Mg}^{2+}$ in the puffed solution. The early current was then strongly and reversibly reduced. ACh: $100 \mu \mathrm{M}$.

Although $I_{\mathrm{c}(\mathrm{ACh})}$ is probably partially carried by $\mathrm{Ca}^{2+}$ ions, its large reduction in absence of external $\mathrm{Ca}^{2+}$ at $V_{\mathrm{hr}}=+32 \mathrm{mV}$ cannot be explained by a decreased $\mathrm{Ca}^{2+}$ influx because it would have led to an opposite effect. Therefore, it might be that extracellular $\mathrm{Ca}^{2+}$ is involved in activation or potentiation of the early current. Such a mechanism has been proposed for nicotinic AChRs of neurons of rat medial habenular nucleus (Mulle et al., 1992).

\section{Isolated early current in the absence of intracellular BAPTA}

Interestingly, $I_{\mathrm{e}(\mathrm{ACh})}$ was occasionally observed in the absence of $I_{\mathrm{K} \text { (ACh) }}$ in OHCs loaded with any of the intracellular solutions 1 to 4 (see Table 1). Indeed, 11 of $109 \mathrm{OHCs}$ exhibited $I_{\mathrm{c}(\mathrm{ACh})}$ after the loss of $I_{\mathrm{K}(\mathrm{ACh})}$. In addition, 9 other cells displayed $I_{\mathrm{c}(\mathrm{ACh})}$ alone from the start of their recording. Similar observations were made by Housley and Ashmore (1991), and this suggests that $\mathrm{Ca}^{2+}$ is not the only coupling factor in the ACh response.

\section{DISCUSSION}

For the first time in mammalian OHCs, we showed that the ACh-induced hyperpolarizing $\mathrm{K}^{+}$current $\left(I_{\mathrm{K}(\mathrm{ACh})}\right)$ is preceded by an early depolarizing current $\left(I_{\mathrm{e}(\mathrm{ACh})}\right)$. We also showed that the $I-V$ relationship of the $\mathrm{ACh}$-induced current displayed an $\mathrm{N}$-shape reminiscent of the behavior of $\mathrm{K}^{+}$current activated secondarily to $\mathrm{Ca}^{2+}$ influx. In addition, the rate of rise of $I_{\mathrm{K} \text { (ACh) }}$ slowed as the driving force on $\mathrm{Ca}^{2+}$ diminished. We also observed 
that, concomitant with $I_{\mathrm{K}(\Lambda \mathrm{Ch})}$ activation, $\mathrm{ACh}$ elicited a $\mathrm{Ca}^{2+}$ response restricted to the synaptic region of OHCs. Furthermore, $I_{\mathrm{K}(\mathrm{ACh})}$ was not additive to photoactivated $I_{\mathrm{K}(\mathrm{Ca})}$ and was prevented in the absence of extracellular $\mathrm{Ca}^{2+}$ or in the presence of $10 \mathrm{~mm}$ intracellular BAPTA. In BAPTA-loaded cells, we could observe $I_{\mathrm{e}(\mathrm{ACh})}$ in isolation, and it appeared to be a nonspecific cation current sensitive to D-TC. Therefore, the simplest explanation is that the mechanism of cholinergic inhibition occurring in mammalian OHCs involves ligand-gated cation channels that allow calcium influx to activate nearby $\mathrm{Ca}^{2+}$-dependent $\mathrm{K}^{+}$channels $\left(\mathrm{K}_{\mathrm{Ca}(\mathrm{ACh})}\right.$ channels). A similar mechanism has been described in avian short hair cells (Fuchs and Murrow, 1992a) and may also occur in central neurons (Wong and Gallager, 1991). Our results complete and are in agreement with the study of Housley and Ashmore (1991), who first described $I_{\mathrm{K}(\mathrm{ACh})}$ in isolated mammalian $\mathrm{OHCs}$, and also with more recent reports (Eróstegui et al., 1994a,b). In contrast, Kakehata et al. (1993) suggested that the $\mathrm{ACh}$ response is mediated by the $\mathrm{IP}_{3}$ cascade because of its disappearance after a few minutes of intracellular dialysis with GDP $\beta$, pertussis toxin (PTX), or heparin. Those data are apparently incompatible with ours. However, one can speculate that the effects of GDP $\beta$ S and PTX were indirect, possibly on a regulatory pathway, and that heparin acted nonspecifically because we report here the absence of response to photoreleased $\mathrm{IP}_{3}$. Finally, Kakehata et al. (1993) recorded little or no inward current in $10 \mathrm{~mm}$ BAPTA-loaded cells, but that was probably attributable to their drug application system. Indeed, we observed that $I_{\mathrm{e} \text { (ACh) }}$ was hardly distinguishable when $\mathrm{ACh}$ was applied from a delivery pipette placed more than $50 \mu \mathrm{m}$ away from the cell, either with the pressure puff ejector or with the U-tubing system.

On the other hand, Ashmore et al. (1992) have reported that $\mathrm{ACh}$ induced a small $\mathrm{Ca}^{2+}$ response restricted to the cell base. We confirm and complete this observation by showing that the $\mathrm{Ca}^{2+}$ rise is concomitant with $I_{\mathrm{K}(\mathrm{ACh})}$ activation. Furthermore, the limited extension of the $\mathrm{Ca}^{2+}$ signal may explain why Dulon et al. (1990) did not record significant ACh-evoked $\mathrm{Ca}^{2+}$ response when integrating Fluo-3 fluorescence from the whole volume of OHCs. In contrast, Doi and Ohmori (1993) have surprisingly reported that $\mathrm{ACh}$ evoked a long-lasting $\mathrm{Ca}^{2+}$ response propagating from the base to the whole cell, but this might be because of the use of ionophoresis for ACh application to unclamped cells. Indeed, because OHCs are very sensitive to electrical stimulation, ionophoresis may alter the cell membrane potential and, therefore, lead to a nonspecific rise in intracellular $\mathrm{Ca}^{2+}$.

Classification of the AChR of the OHCs in the nicotinic family is based in our study on its ionotropic nature leading to a nonspecific cation current and on its sensitivity to curare. However, the strong outward rectification of $I_{\mathrm{e}(\mathrm{ACh})}$ suggests that AChRs of OHCs differ from most known neuronal nicotinic AChRs (N-nAChRs) (Mathie et al., 1987, 1990; Yawo, 1989) and, to a lesser extent, from muscle nAChRs (M-nAChRs) (Takeuchi and Takeuchi, 1959; Kordaö, 1969; Magleby and Stevens, 1972; Linder and Quastel, 1978). Interestingly, the "nicotinic-like" current of chick short hair cells also displays outward rectification (see Fig. 10 of Fuchs and Murrow, 1992). This outward rectification might be attributable to a particular sensitivity of the receptor to extracellular divalents because, in high concentration, they could lead to similarly strong outward rectification of nicotinic currents flowing through single M- and N-nAChRs (Dani and Eisenman, 1987; Ifune and Steinbach, 1991). Otherwise, several studies have shown the unusual pharmacological properties of the cholinergic re- sponse of hair cells (Housley and Ashmore, 1991; Fuchs and Murrow, 1992b; Kakehata et al., 1993; Eróstegui et al., 1994a). These unusual properties are consistent with those of the recently discovered $\alpha 9$ nAChR subunit because the $\alpha 9$ homomeric receptor-channel complex displays a remarkably similar pharmacological profile (Elgoyhen et al., 1994). Furthermore, mRNAs of the $\alpha 9 \mathrm{nAChR}$ subunit are expressed in rat OHCs (Elgoyhen et al., 1994; Glowatzki et al., 1995). Therefore, it appears highly probable that the hair cell nAChRs (HC-nAChRs) contain $\alpha 9$ subunits. It is interesting, therefore, to note that $\alpha 9$ homomeric receptor-channel complexes, as $\mathrm{N}$-nAChR channels, allow $\mathrm{Ca}^{2+}$ influx large enough to trigger $\mathrm{Ca}^{2+}$-dependent $\mathrm{Cl}^{-}$currents in Xenopus oocytes (Vernino et al., 1992; Elgoyhen et al., 1994). In similar conditions, $\mathrm{Ca}^{2+}$ can carry $4-5 \%$ of the inward current flowing through N-nAChRs (Sands and Barish, 1991; Vernino et al., 1994). If HC-nAChRs have such $\mathrm{Ca}^{2+}$ permeability, a very small $\mathrm{Ca}^{2+}$ influx should occur because $I_{\mathrm{c}(\mathrm{ACh})}$ averaged $100 \mathrm{pA}$ at resting membrane potential. This may explain the small and regionalized $\mathrm{Ca}^{2+}$ response observed in confocal calcium imaging. This small $\mathrm{Ca}^{2+}$ influx induced by $\mathrm{ACh}$, however, is able to trigger a much larger $\mathrm{K}^{+}$current within a few milliseconds. Furthermore, activation of $I_{\mathrm{K}(\mathrm{ACh})}$ could be prevented when OHCs were dialyzed with BAPTA at a concentration of $10 \mathrm{~mm}$ but not at $5 \mathrm{~mm}$. These features imply that $\mathrm{HC}$-nAChRs and $\mathrm{K}_{\mathrm{Cn}(\mathrm{ACn})}$ channels are colocalized. As suggested by Figure $5 b, \mathrm{~K}_{\mathrm{Ca}(\mathrm{ACh})}$ channels appear spatially segregated from other $\mathrm{Ca}^{2+}$-dependent $\mathrm{K}^{+}$channels. The latter are likely "maxi" $\mathrm{K}^{+}$channels because they are sensitive to charybdotoxin (our unpublished observations) and blocked by internal Cs ${ }^{1}$ ions (Fuchs and Evans, 1990; Housley and Ashmore, 1992). As reported previously (Fuchs and Murrow, 1992a; Eróstegui et al., 1994a,b), we showed that $\mathrm{K}_{\mathrm{Ca}(\mathrm{ACh})}$ channcls are not blocked by $\mathrm{Cs}^{+}$ions. Therefore, the apparent spatial segregation of the two types of $\mathrm{Ca}^{2+}$-activated $\mathrm{K}^{+}$channels, possibly corresponding to those described by Ashmore and Meech (1986), may be attributable to their involvement in different physiological pathways because $\mathrm{K}_{\mathrm{Ca}(\mathrm{ACh})}$ channels and maxi $\mathrm{K}^{+}$channels are associated with $\mathrm{HC}-\mathrm{nAChRs}$ and voltage-gated $\mathrm{Ca}^{2+}$ channels (Roberts, 1993), respectively.

Finally, it is worth mentioning the unique ultrastructural organization of the hair cell efferent synapse. Indeed, a subsynaptic cisterna, coextensive with each efferent ending, lies 10-20 nm beneath the postsynaptic membrane (Saito, 1980). Although a $\mathrm{Ca}^{2+}$-induced $\mathrm{Ca}^{2+}$ release from this subsynaptic cisterna might be involved in the $\mathrm{ACh}$ response, such a mechanism does not appear to be necessary. As proposed for the chick hair cell efferent synapse (Martin and Fuchs, 1992), $\mathrm{Ca}^{2+}$ influx through $\mathrm{HC}-\mathrm{n} \Lambda \mathrm{ChRs}$ into the restricted area delimited by the postsynaptic membrane and the subsynaptic cisterna should allow a rapid and large enough rise of free $\mathrm{Ca}^{2+}$ level to activate nearby $\mathrm{Ca}^{2+}$ dependent $\mathrm{K}^{+}$channels. This fits well with our observation of a small $\mathrm{ACh}$-evoked $\mathrm{Ca}^{2+}$ response localized at the cell base. Moreover, the dependence of the rate of rise and deactivation of $I_{\mathrm{K} \text { (ACh) }}$ on membrane potential also argues in favor of a $\mathrm{Ca}^{2+}$ accumulation in a restricted diffusion zone. Otherwise, the striking observation in the absence of intracellular BAPTA of $I_{\mathrm{e}(\mathrm{ACh})}$ after the loss of $I_{\mathrm{K}(\mathrm{ACl})}$ might be attributable to the disruption of subsynaptic cysterna, thus uncoupling $\mathrm{HC}-\mathrm{nAChRs}$ and $\mathrm{K}_{\mathrm{Ca}(\mathrm{ACh})}$ channels. Finally, recent observations in our laboratory reinforce our conviction that the subsynaptic cisterna plays a prominent role in the cholinergic response. Indeed, during postnatal maturation of the rat cochlea, the $\mathrm{ACh}$ response of OHCs changes from a depolarizing nicotinic-like current to the adult hyperpolarizing $\mathrm{K}^{+}$ 
current and, interestingly, this shift occurs concomitantly with the formation of the subsynaptic cisterna (D. Dulon and M. Lenoir, unpublished observations). Therefore, it seems that a high degree of postsynaptic specialization, including the colocalization of two specific channels, has been selected to allow fast cholinergic inhibition of OHCs. This inhibition probably arises from clamping the cell membrane potential to $E_{\mathrm{K}}$. Because of the nonlinearity of electromotile responses (Santos Sacchi, 1989), voltage-dependent movements of OHCs are reduced at such hyperpolarized potentials. Efferent nerve stimulation would then decrease the efficiency of the cochlear amplifier.

\section{REFERENCES}

Ashmore JF (1987) A fast motile response in guinea-pig outer hair cells: the cellular basis of the cochlear amplifier. J Physiol (Lond) 388:323-347.

Ashmore JF, Meech RW (1986) Ionic basis of membrane potential in outer hair cells of guinea pig cochlea. Nature 322:361-371.

Ashmore JF, Housley GD, Kolston PJ (1992) Two control systems for the vuter hair cell motor. In: Advances in the biosciences, Vol 83, pp 19-26. New York: Pergamon.

Blanchet C, Dulon D (1993) Evidence that ACh triggers a $\mathrm{Ca}^{2+}$. dependent $\mathrm{K}^{+}$current in guinea-pig outer hair cells. 30th Inner Ear Biology Workshop, Abstract 66.

Blanchet C, Dulon D (1994a) Implication of $\mathrm{Ca}^{2+}$ in the electrical response generated by $\mathrm{ACh}$ in guinea pig outer hair cells. Midwinter Research Meeting. Association for Research in Otolaryngology, Abstract 505 .

Blanchet C, Dulon D (1994b) Ionic currents elicited by acetylcholine in guinea-pig outer hair cells. 31st Inner Ear Biology Workshop, Abstract P55.

Blanchet C, Eróstegui C, Sugasawa M, Dulon D (1995) Effect of extracellular calcium on the nicotinic-like current of guinea pig outer hair cells. 32nd Inner Ear Biology Workshop, Abstract P4.

Bobbin RP, Konishi T (1971) Acetylcholine mimics crossed olivocochlear bundle stimulation. Nature 231:222-223.

Brownell WE, Bader CR, Bertrand D, de Ribeaupierre Y (1985) Evoked mechanical responses of isolated cochlear hair cells. Science 227:194-196.

Canlon B, Cartaud J, Changeux JP (1989) Localization of $\alpha$-bungarotoxin binding sites on outer hair cells from the guinea-pig cochlea. Acta Physiol Scand 137:549-550.

Dani JA, Eisenman G (1987) Monovalent and divalent cation permeation in acetylcholine receptor channels. J Gen Physiol 89:959-983.

Doi 'I, Ohmori H (1993) Acetylcholine increases intracellular $\mathrm{Ca}^{2+}$ concentration and hyperpolarizes the guinea-pig outer hair cell. Hear Res 67:79-183.

Dulon D, Zajic G, Schacht J (1990) Increasing intracellular free calcium induces circumferential contractions in isolated outer hair cells. J Neurosei 10:1388-1397.

Dulon D, Zajic G, Schacht J (1991) Differential motile response of isolated inner and outer hair cells to stimulation by potassium and calcium ions. Hear Res 52:225-232.

Dulon D, Zajic G, Schacht J (1993a) InsP $P_{3}$ releases intracellular stored calcium in Deiters' cells of the organ of Corti. Midwinter Research Meeting. Association for Research in Otolaryngology, Abstract 466.

Dulon D, Moataz R, Mollard P (1993b) Characterization of $\mathrm{Ca}^{2+}$ signals generated by extracellular nucleotides in supporting cells of the organ of Corti. Cell Calcium 14:245-254.

Dulon D, Blanchet B, Laffon E (1994) Photo-released intracellular $\mathrm{Ca}^{2+}$ evokes reversible mechanical responses in supporting cells of the guinea-pig organ of Corti. Biochem Biophys Res Commun 201:1263-1269.

Dulon D, Sugasawa M, Blanchet C, Eróstegui C (1995) Direct measurements of $\mathrm{Ca}^{2+}$ activated $\mathrm{K}^{+}$currents in inner hair cells of the guinea-pig cochlea using photolabile $\mathrm{Ca}^{2+}$ chelators. Pflügers Arch 430:365-373.

Elgoyhen AB, Johnson DS, Boulter J, Vetter DE, Heinemann S (1994) $\alpha 9$ : an acetylcholine receptor with novel pharmacological properties expressed in rat cochlear hair cells. Cell 79:705-715.

Eróstegui C, Norris CH, Bobbin RP (1994a) In vitro characterization of cholinergic receptor on outer hair cells. Hear Res 74:135-147.
Eróstegui C, Nenov A, Norris C, Bobbin RP (1994b) Acetylcholine activates a $\mathrm{K}^{+}$conductance permeable to $\mathrm{Cs}^{+}$in guinea-pig outer hair cells. Hear Res 81:119-129.

Eybalin M (1993) Neurotransmitters and neuromodulators of the mammalian cochlea. Physiol Rev 73:309-373.

Fex J, Altschuler RA (1986) Neurotransmitter-related immunohistochemistry of the organ of Corti. Hear Res 22:249-263.

Fuchs PA, Nagai T, Evans MG (1988) Electrical tuning in hair cells isolated from the chick cochlea. J Neurosci 8:2460-2467.

Fuchs PA, Evans MG (1990) Potassium currents in hair cells isolated from the cochlea of the chick. J Physiol (Lond) 429:529-551.

Fuchs PA, Murrow BW (1992a) Cholinergic inhibition of short (outer) hair cells of the chick's cochlea. J Neurosci 12:800-809.

Fuchs PA, Murrow BW (1992b) A novel cholinergic receptor mediates inhibition of chick cochlcar hair cclls. Proc R Soc Lond [Biol] 248:35-40.

Galambos R (1956) Suppression of auditory nerve activity by stimulation of efferent fibers of the cochlea. J Neurophysiol 19:424-437.

Glowatzki E, Wild K, Brändel U, Falker G, Falker B, Zenner HP, Ruppersberg JP (1995) Cell-specific expression of the $\alpha 9 \mathrm{n}$-ACh receptor subunit in auditory hair cells revealed by single-cell RT-PCR. 32nd Inner Ear Biology Workshop, Abstract O35.

Hamill OP, Marty A, Neher E, Sakmann B, Sigworth FJ (1981) Improved patch-clamp techniques for high-resolution current recording from cells and cell-free membrane patches. Pflügers Arch 391:85-100.

Ilousley GD, Ashmore JF (1991) Direct measurement of the action of acetylcholine on isolated outer hair cells of the guinea-pig cochlea. Proc R Soc Lond [Biol] 244:161-167.

Housley GD, Ashmore JF (1992) Ionic currents of outer hair cells isolated from the guinea-pig cochlea. J Physiol (Lond) 448:73-98.

Housley GD, Greenwood D, Ashmore JF (1992) Localization of cholinergic and purinergic receptors of outer hair cells isolated from the guinea-pig cochlea. Proc R Soc Lond [Biol] 249:265-273.

Ifune CK, Steinbach JH (1991) Voltage-dependent block by magnesium of neuronal nicotinic acetylcholine receptor channels in rat phaeochromocytoma cells. J Physiol (Lond) 443:683-701.

Kakeliata S, Nakagawa T, Takasaka T, Akaike N (1993) Cellular mechanism of acetylcholine-induced response in dissociated outer hair cells of guinea-pig cochlea. J Physiol (Lond) 463:227-244.

Kaplan JH, Ellis-Davies GCR (1988) Photolabile chelators for rapid photolytic release of divalent cations. Proc Natl Acad Sci USA 85:6571-6575.

Kordaö M (1969) The effect of membrane polarization on the time course of the end-plate current in frog sartorius muscle. J Physiol (Lond) 204:493 502.

Lancaster B, Zucker RS (1994) Photolytic manipulation of $\mathrm{Ca}^{2+}$ and the time course of slow, $\mathrm{Ca}^{2+}$-activated $\mathrm{K}^{+}$current in rat hippocampal neurons. J Physiol (Lond) 475:229-239.

Linder TM, Quastel DM (1978) A voltage-clamp study of the permeability change induced by quanta of transmitter at the mouse end-plate. J Physiol (Lond) 281:535-556.

Magleby KL, Stevens CF (1972) A quantitative description of end-plate currents. I Physiol (I ond) 223:173-197.

Martin AR, Fuchs PA (1992) The dependence of calcium-activated potassium currents on membrane potential. Proc R Soc Lond [Biol] 250:71-76.

Mathie A, Cull-Candy SG, Colquhoun D (1987) Single-channel and whole-cell currents evoked by acetylcholine in dissociated sympathetic neurons of the rat. Proc R Soc Lond [Biol] 232:239-248.

Mathie A, Colquhoun D, Cull-Candy SG (1990) Rectification of currents activated by nicotinic acetylcholine receptors in rat sympathetic ganglion neurones. J Physiol (Lond) 427:625-655.

Meech RW, Standen NB (1975) Potassium activation in Helix aspersa neurones under voltage clamp: a component mediated by calcium influx. J Physiol (Lond) 249:211-239.

Mulle C, Léna C, Changeux JP (1992) Potentiation of nicotinic receptor response by external calcium in rat central neurons. Neuron 8:937-945.

Norris CH, Guth PS (1974) The release of acetylcholine by the crossed olivo-cochlear bundle. Acta Otolaryngol 77:318-326.

Plinkert PK, Gitter AH, Zimmerman U, Kirchner T, Tzartos S, Zenner HP (1990) Visualization and functional testing of acetylcholine receptor-like molecules in cochlear outer hair cells. Hear Res 44:25-34.

Roberts WM (1993) Spatial calcium buffering in saccular hair cells. Nature 363:74-76. 
Saito K (1980) Fine structure of the sensory epithelium of the guinea pig organ of Corti: afferent and efferent synapses of hair cells. J Ultrastruct Res 71:222-232.

Sands SB, Barish ME (1991) Calcium permeability of neuronal nicotinic acetylcholine receptor channels in PC12 cells. Brain Res 560:38-42.

Santos-Sacchi J (1989) Asymmetry in voltage-dependent movements of isolated outer hair cells from the organ of Corti. J Neurosci 9:2954-2962.

Santos-Sacchi J, Dilger JP (1988) Whole cells currents and mechanical responses of isolated outer hair cells. Hear Res 35:143-150.

Takeuchi A, Takeuchi N (1959) Active phase of frog's end-plate potential. J Neurophysiol 22:395-411.

Tsien R (1980) New calcium indicators and buffers with high selectivity àgainst magnesium and protons: design, synthesis, and properties of prototype structures. Biochemistry 19:2396-2404.
Vernino S, Amador M, Luetje C, Patrick J, Dani JA (1992) Calcium modulation and high calcium permedbility of neuronal nicotinic acetylcholine receptors. Neuron 8:127-134.

Vernino S, Rogers M, Radcliffe KA, Dani JA (1994) Quantitative measurement of calcium flux through muscle and neuronal nicotinic acetylcholine receptors. J Neurosci 14:5514-5524.

Walker JW, Feeney J, Trentham DR (1989) Photolabile precursors of inositol phosphates: preparation and properties of 1-(2nitrophenyl)ethyl esters of myo-inositol 1,4,5-trisphosphate. Biochemistry $28: 3272-3280$

Wong LA, Gallagher JP (1991) Pharmacology of nicotinic receptormediated inhibition in rat dorsolateral septal neurones. J Physiol (Lond) 436:325 346

Yawo H (1989) Rectification of synaptic and acetylcholine currents in the mouse submandibular ganglion cells. J Physiol (Lond) 417:307-322. 